\title{
XXVII. On the direction of the diluvial currents in Yorkshire
}

\section{John Phillips M.Y.P.S.}

To cite this article: John Phillips M.Y.P.S. (1827) XXVII. On the direction of the diluvial currents in Yorkshire, Philosophical Magazine Series 2, 2:8, 138-141, DOI: $\underline{10.1080 / 14786442708674423}$

To link to this article: http://dx.doi.org/10.1080/14786442708674423

曲 Published online: 10 Jul 2009.

Submit your article to this journal ¿

Џll Article views: 3

Q View related articles $\sqsubset$ 
The structure of some other parenchymatous parts appears equally indeterminate, presenting neither globule nor fibre.

Pus.-As far as we have yet examined this secretion, its particles appear to be as irregular in size and figure as those observed in the brain, and bear no resemblance to those of the blood.

Milk.-In this fluid the particles appear to be perfect globules. But, far from being uniform, they present the most remarkable varieties in respect to size. Whilst some are more than double, others are not a tenth part of the size of the particles of the blood, to which they bear no resemblance.

I forbear at present offering any remarks which the preceding observations would suggest.

XXVII. On the Direction of the DiluvialCurrents in Yorkshire. By John Phillips, M.Y.P.S. Lecturer on Gealogy*.

MR. WILLIAM SMITH has been represented by Mr. I Greenough as favouring the opinion that in our island the waters of the deluge moved generally from east to west. Mr. Smith, I believe, when he used these expressions in conversation, had in view merely to explain the occurrence of chalk gravel in Warwickshire and Lincolnshire, and of chalk flints on the oolite hills near Bath.

Dr. Buckland, who in his "Reliquice Diluviane" has so well expressed and enforced the general sentiments of English geologists, as to be with justice regarded as the great advocate and interpreter of the diluvial theory, has adduced evidence by which he thinks he has made probable the opinion of a general southward current.

In the remarks which I have now to offer to the Society, it is not my intention to travel over so wide a field. I rather wish to confine my observations to some facts which I think tend to show the direction of the diluvial waters across part of Yorkshire, and of some neighbouring counties. For this object I shall extract from my Journal some localities where boulders have been seen of rocks so peculiarly characterized as to allow no doubt of the spots from whence they were dislodged.

Shap and Birkbeck fells in Westmoreland, between Penrith and Kendal, are elevated in some parts about 1500 feet above the sea. Lying on the eastern skirts of the mountain group which incloses the lakes of Cumberland, Westmore-

* Read to the Yorkshire Philosophical Society, Nov. 7, 1826; and communicated by the Society. 
land, and Lancashire, they are environed by high ground on the south-east, south, and west sides: toward the north-east and east are lower ranges of mountain-limestone; beyond them is spread the wide vale of Eden, and the distance is formed by the long range of mountain-limestone which, from Ingleborough to Castle Carrock fell, presents to the west an escarpment varying in height from 1500 to 1900 feet. Stainmoor Forest, the lowest part of this great range, lying east of Shap fells, is 1500 feet above the sea.

Shap fells, like all the contiguous mountain tracts, are composed principally of various argillaceous slate rocks; but on the side of the Penrith and Kendal road appears a particular kind of porphyritic granite, composed of light-coloured felspar, grayish quartz, and dark mica, and inclosing abundance of large well-defined crystals of red felspar. The aspect of the rock is very characteristic, and its fragments are recognized at first sight.

No such granite is found in situ in any other part of the Cumbrian lake district: and there is no danger of confounding with it any Scotch granite, that I am acquainted with, except some varieties that may be collected in Ben Nevis; and these may be distinguished on careful inspection.

The granite of Shap fells seems therefore particularly worthy of their attention, who would trace practically from point to point the direction of diluvial currents.

Last summer (1826) I observed large boulders of this granite in the low ground about a mile south of Carlisle, and on an elevated red-sandstone fell north-west of Kirk Oswald. Abundance of boulders of this granite, lie some miles north of their native site, near the villages of Shap and Great Strickland.

In a southern direction, such large boulders are seen lying on the hills between Kendal and Sedbergh : they are common in the vale of the Lune, with many pebbles seemingly derived from the neighbouring hills of argillaceous slate; and were found of a ton weight in the vast heaps of diluvial matter cut through in the canal south of Lancaster.

Eastward from Shap fells, this granite has been rolled by the towns of Orton and Brough toward the hollow in the great summit ridge at Stainmoor, on the top of which pass the blocks remain, to attest the direction and force of the transporting waters. From this point the granitic boulders seem to have been dispersed in different directions; as we find them in Teesdale, at Cotherstone, below Barnard-castle near Greta Bridge, and Darlington, at Scotton, south of Richmond, at Catterick, and Leeming, at Stokesley, and Thirsk, and several places beT 2 
low the range of oolitic rocks between Thirsk and Pocklington, and commonly in gravel-pits and on the surface of the country around York. But this is by no means their eastern limit; for I have observed them of great size at several points on the Yorkshire coast between Redcar and Scarborough, where they are very plentiful on the shore, and are occasionally found inland, as about 300 feet high in cutting a new road toward Hackness, on the hill side above Scalby : and, to complete the evidence, they are seen lying on the cliff at Flamborough head, above 100 miles from their native situation.

An observer stationed on Shap fells sees the country to the north and east a good deal lower than the point where the granite appears in situ, and may therefore feel no particular surprise that blocks should have been transported into the vale of Eden; nor does it appear strange that they sbould have followed the vale of Lume to Lancaster. These effects might possibly have happened in consequence of the bursting of an elevated lake, according to Dr. Fleming's view; but that the bursting of such a lake, in the vicinity of Shap fells, could effect the transport of granite blocks across the deep vale of Eden, over the summit of Stainmoor, and down the valleys and over the hills of Yorkshire, to Scarborough and Flamborough head, I tind myself incapable of admitting. This case has always appeared to me decisive in favour of the opinion, that the dispersion of gravel over large tracts is attributable to the deluge.

From the facts above mentioned, I am induced to suppose that the flood of waters, which rolled away blocks of granite from Shap fells, moved principally in an eastward or rather south-eastward direction; and that the dispersion of fragments toward other points may have happened, in consequence of contemporaneous or subsequent minor currents, down the valleys of Eden and Iune.

The next rock, whose bouldered fragments I propose to notice, occurs in situ on the precipitous sides of Carrock fell, one of a group of Cumberland mountains lying to the northeast of Skiddaw. It is a compound of white compact felspar and large-grained dark hornblende, in variable proportion, with here and there some magnetic iron-ore.

To the north, bouldered blocks of great size are seen somewhat thinly scattered between Hesket, Newmarket, and Bolton. I have noticed them near Kirk-Oswald, on high ground west of the Eden: they abound about Lowther Castle; and I broke one large mass, which at the time I considered to be a pebble of this rock, near Lord Darlington's smelt-mill at the west pits in Durham. 
The third rock is fully as remarkable and local as either of the others. It consists of pebbles of light-coloured mountainlimestone, united together by red sandstone into a conglomerate provincially called brockram. This occurs in situ, sometimes alternating with red sandstone, abundantly about Kirkby Stephen, in Westmoreland, as at Stenkrith Bridge, where the Eden has forced through it a romantic and beautiful channel.

I have observed pebbles of this curious rock at Scotton, south-east of Richmond, and at several places on the Yorkshire coast, especially at Scarborough, Bridlington, and south of Owthorne, in Holderness.

Clearly as these examples seem to indicate that over parts of Cumberland, Westmoreland, Yorkshire, and Durham, the principal force of the diluvial waters was exerted in an eastward or rather south-eastward direction, they are not the only ones which lead to such a conclusion. Analogous instances will occur to every one who examines the great variety of boulders which are found in several parts of Yorkshire, especially on the coast of Holderness, and in the neighbourhood of York.

But in both these localities we find fragments of rocks that can only be supposed to have been transported by a different current flowing from the north. The large blocks of limestone, trap, millstone-grit and other sandstones, coal, and magnesian limestone, which appear on the coast of Holderness, may well be admitted to have been derived from north-western Yorkshire, where such rocks abound. But mica slate with garnets, which nowhere occurs in the Cumbrian mountains, is probably derived from Scotland; the radiated fetid limestone clearly claims origin from Building hill near Sunderland, and the lias fossils have been rolled from Whitby: these effects seem to require the admission of a powerful southward flow of waters; and, in the Vale of York, lias fossils from the north, chalk and oolite fragments from the north-east, are mixed with the debris of rocks washed from the north-western part of the county.).

Perhaps, on a future occasion, I may offer some adcitional statements on this subject, not undeserving the attention of a Society which, in consequence of its possessing a fine series of the remains of antediluvian animals procured in the neighbourhood of its museum, must feel a particular interest in the progress of geological opinions respecting the deluge. 